\title{
EVALUATION OF THE SCHOOL OF PHYSICAL EDUCATION AND SPORTS STUDENTS' LEARNING STYLES ACCORDING TO THE GREGORC LEARNING STYLE ${ }^{1}$
}

\section{GREGORC ÖĞRENME STILINE GÖRE BEDEN EĞITIMI SPOR YÜKSEKOKULU ÖĞRENCILERININ ÖĞRENME STILLERININ İNCELENMESI}

\author{
Mehmet YANIK
}

Balıkesir Üniversitesi, Beden Ĕ̆itimi ve Spor Yüksekokulu Balıkesir / Türkiye

Öz: Bu çalışmada beden eğitimi ve spor yüksekokulu öğrencilerinin (BESYO) Gregorc öğrenme stiline göre tercih ettikleri öğrenme stillerinin belirlemesi ve bu tercihlerinin bazı değişkenler bakımından incelenmesi amaçlanmıştır. İlişkisel tarama modelinin kullanıldığı bu çalışma Balıkesir Üniversitesi, Beden Eğitimi ve Spor Yüksekokulunda öğrenim gören ve tesadüfi örneklem metodu ile seçilen toplam 480 (nmen=223,nwomen=257) öğrenci ile yürütülmüştür. Veri toplama aracı olarak "Gregorc Öğrenme Stilleri Ölçeği”" ve "Kişisel Bilgi Formu" kullanılmıştır. Verilerin analizinde; frekans ve yüzde dökümleri alınmış, Kaykare (X2) testi kullanılmıştır. Yapılan analizler sonunda çalışmaya katılan BESYO öğrencilerinden 36,9 $\%$ bölümünün Somut Rastgele $(\mathrm{Cr})$ öğrenme stilini tercih ettikleri tespit edilmiştir. Pes öğrencilerinin öğrenme stillerinin cinsiyet, öğrenim görülen bölüm ve alg1lanan akademik başarı değişkenleri ile arasında anlamlı bir ilişkinin olmadığı ( $p>0.05)$, sınıf seviyesi değişkeni ile aralarında anlamlı bir farklılık olduğu $(\mathrm{p}<0.05)$ görülmüştür. Buna göre Beden eğitimi ve spor yüksekokullarındaki ders içeriklerinin planlanmasında öğrencilerin baskın olan öğrenme stilleri dikkate alınarak uygun öğretim yöntemleriyle derslerin işlenmesi ve ders müfredatlarının buna göre hazırlanması önerilmektedir.

Anahtar Kelimeler: Öğrenme Stili, Müfredat, Eğitimde Bireysel Farklılıklar, Beden Eğitimi ve Spor Yüksekokulu Programı
Abstract: This study aims to determine the learning styles preferred by Physical Education and Sports School (PES) students according to the Gregorc learning style and to evaluate these preferences with regard to some variables. This study uses the relational screening model and was conducted on 480 (nmale $=223$,nfemale $=257$ ) students attending Balıkesir University Physical Education and Sports School selected using random sampling method. "Gregorc Learning Style Delineator" and "Personal Information Form" have been used as a data collection tool. The analysis has determined that, out of all the PES students which took part in the study, $36.9 \%$ prefer the concrete random (CR) learning style. Taking into account the results of this research, it is strongly suggested that the dominant learning styles of the students be taken into account when planning the content of the curriculum and during the teaching phase at physical education and sports schools.

Key Words: Learning style, Curriculum, Individual differences in education, Physical Education and Sports School

Doi: 10.17363/SSTB.20161919749

(1) Corresponding Author: Mehmet YANIK, Balkesir Üniversitesi, Beden Eüitimi ve Spor Yüksekokulu Balıkesir / Türkiye memetgym@hotmail.com Received: 11.03.2016 Accepted: 29.05.2016 Type ofarticle (Research and Practice) Conflict of Interest: None Ethics Committee: None 


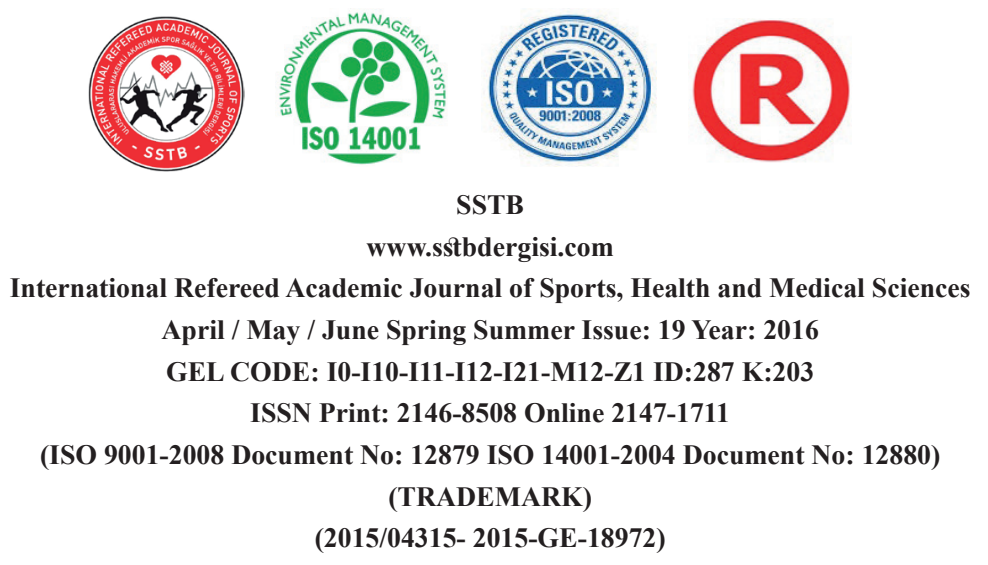

\section{INTRODUCTION}

In this day and age, with regards to the quality of education, it is imperative that the differences between individuals within the same learning environment be taken into consideration. Each individual's preferences regarding the perception, coding and processing of information is different. These differences between students also affects their learning processes. The difference between the perception and success levels of individuals who have passed through the same learning processes is the most convincing proof of this. This has increased the need to take into account the individual differences in learning.

The most basic difference in learning is the individuals' learning style. Learning style is defined as how a student learns something, rather than what a student learns (Hunt, 1979) as cited in (Yenice \& Saracaloğlu, 2009). In other words, learning style is the process of taking in, processing information and putting forth a new product using this information. The literature on the subject defines learning style in a number of ways. Dunn and Dunn (1993) defined learning style as "The different way in which each learner begins to concentrate on and then process and retain new and difficult information", while Kolb (2005) defined it as "the method an individual personally prefers during the process of perceiving and processing information".
In the education field, every student's learning style and learning needs differs. Increasing the learning success of students who have adopted different learning styles will be possible only through the determination of their individual differences in this regard. The differences in learning styles requires teaching professionals to present their teaching methods and course materials in different ways (Boatman et al., 2008). Therefore, good planning is very important for the teaching-learning process (Silver, Strong \& Perini, 1997).

Process-oriented planning created for the learning process as a result of the identification of individual learning styles will provide a great source of convenience for curriculum planners and practitioners and facilitate the achievement of set teaching goals. Many previous studies have pointed out that teaching plans created in accordance with the students' learning styles in learning environments have increased success rates (Burns et al,.1998; Gorevanova, 2000). Gregorc Learning Style Model is one of the learning style models developed in this regard and is used in this study. This model focuses on methods of perception, process, retention and decoding of information. According to Gregorc; learning styles of an individual consist of the learning states they formed with respect to their perception skills (Gregorc, 1984). 


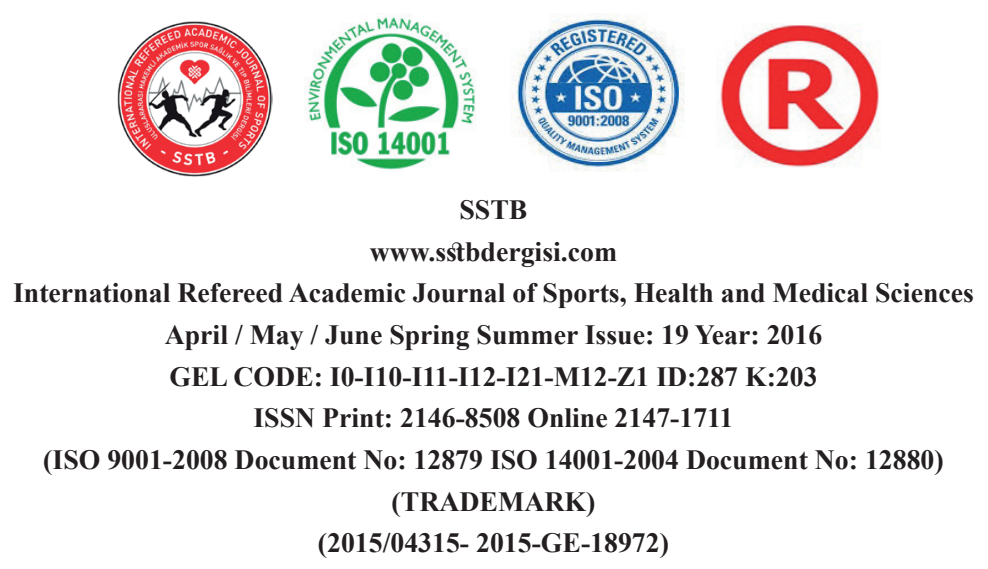

It is important to shape teaching methods with regard to the target group of the process. Using methods and techniques befitting the student during curriculum planning will affect the success of this process. To be more specific, individual learning style is the most important component to keep in mind when preparing curriculum. The literature on the subject shows many studies proving this (Kılıç, 2002; Bahar et al., 2009). Learning consists of various components coming together in a suitable environment and under suitable conditions; therefore, learning will occur only so far as these components are sufficient.

Physical education and sports schools are departments which conduct both theoretical and practical lessons and which question both the level of talent and academic achievement of individuals during the student selection process. A literature survey has shown that there has been a very limited number of studies conducted in order to determine the learning styles of students enrolled in these departments (Grenier, 2006; Yalız \& Erişti, 2009; Ristori et al.,2011). It is stipulated that the determination of physical education and sports school students' learning styles will influence the restructuring of their curriculum. Therefore, this study aims to answer the following question; "What is the distribution of the learning styles of physical education and sports school students?"

\section{METHODOLOGY}

Model Research: This is a descriptive study conducted using the relational screening model which aims to evaluate the learning styles preferred by physical education and sports school students with respect to certain variables.

Participants: The study is conducted at Balıkesir University Physical Education and Sports School, which has a total of 950 students enrolled in the 2014-2015 academic year in 3 different departments (Physical Education Teaching Department, Sports Coaching Education Department and Sports Management Department). During the course of the study a total of 600 students were given the delineator and delineators deemed incomplete or incorrect were removed from the study; thus the study was concluded with 480 students.

$46.5 \%$ of students participating in the study were male $\left(n_{\text {male }}=223\right)$, while $53.5 \%$ were female $\left(n_{f e-}\right.$ male $=257)$. If analyzed according to their departments; $23.3 \%(n=126)$ of the participants were enrolled in the teaching department, 40.4\% $(n=194)$ were enrolled in the coaching department and $33.3 \%(n=160)$ were enrolled in the sports management department. If analyzed according to their academic level, $33.3 \%(n=160)$ of the participants are freshmen, $40.0 \%(\mathrm{n}=192)$ are sophomores, $20.0 \%(\mathrm{n}=96)$ are juniors and $6.7 \%$ $(n=32)$ are seniors. When asked about their perceived academic success levels, $2.9 \%(n=14)$ of 


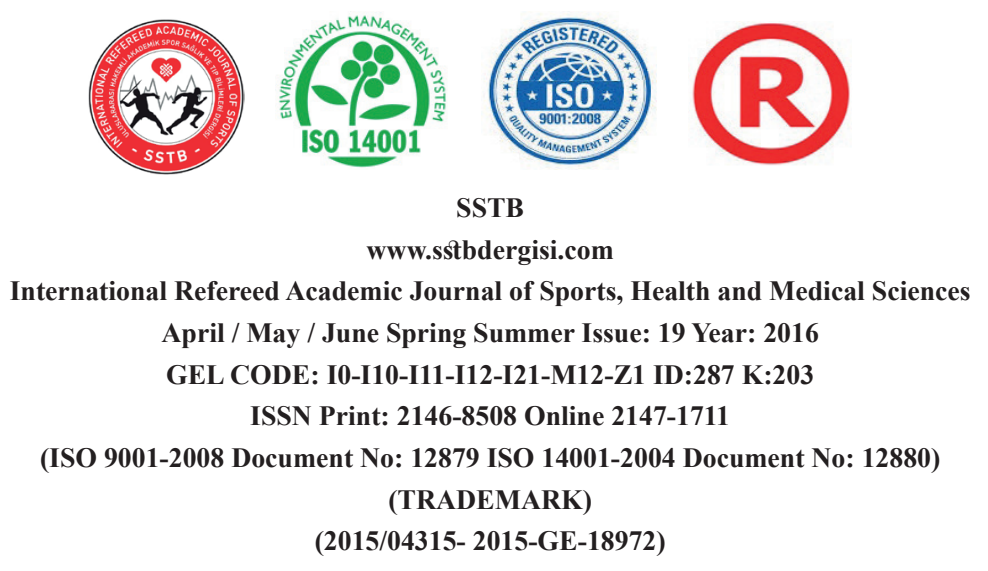

the participants replied very bad, $22.3 \%(\mathrm{n}=107)$ replied bad, 20.4\% $(n=146)$ replied good and $8.8 \%(\mathrm{n}=42)$ replied with very well.

Data Collection Tools: Two data collecting tools were used in this research; a "Personal Information Form" prepared by the researcher and the "Gregorc Learning Styles Delineator", which was developed by Anthony F. Gregorc (1982a; 1982b) and adapted to Turkish by Ekici (2002), who also conducted its the validity and reliability studies. The delineator describes the concrete sequential, abstract sequential, concrete random and the abstract random learning styles. The Gregorc Learning Style Delineator consists of 10 items with 4 options each and participants are asked to put the concepts in those articles in order within themselves marked as 1, 2, 3, 4 according to their importance. Each option contained in the questions corresponds with one of the 4 learning styles (Gregorc, 1982a). The Cronbach-Alpha reliability factors of the delineator have been determined as 0.76 for the concrete sequential learning style, 0.72 for the abstract sequential learning style, 0.75 for the concrete random learning style and 0.80 for the abstract random learning style (Ekici, 2002).

Data Collection: A permit has been obtained from the Physical Education and Sports School administration in the 2014-2015 spring semester in order to conduct the study and collect the research data. Afterwards, having consulted and gotten permission from the department heads, the researcher conducted the study on the day and time they appointed. The researcher informed the students of the aim and importance of the study beforehand. The study has been conducted in accordance with the Helsinki Declaration and the institutional ethical requirements for human experimentation. It has been observed that the students completed the data collection tools within 20-25 minutes.

Data Analysis: In determining the learning styles of the students, the study benefited from frequency and percentages. The study used the Pearson Chi-Square $\left(\mathrm{X}^{2}\right)$ test in the numerical comparisons aimed at determining whether the students' learning styles differed due to various characteristics. Statistical analyses were performed using SPSS statistical software package. In the statistical analyses, the relevance level was taken to be $p<0.05$.

\section{RESULTS}

This section contains tables with comments on the results obtained from the Gregorc Learning Style Delineator and results of the statistical analyses of the data collected towards for research purposes, as well their explanations. 


\begin{tabular}{|c|c|c|}
\hline \multicolumn{3}{|c|}{$\begin{array}{r}\text { International Refereed Academic Jour } \\
\text { April / May / June Spring } \\
\text { GEL CODE: I0-I10-I11-I } \\
\text { ISSN Print: 2146- } \\
\text { (ISO 9001-2008 Document No: 1287 } \\
(\text { TRAI } \\
(2015 / 04315-\end{array}$} \\
\hline \multicolumn{3}{|c|}{$\begin{array}{l}\text { ncy Analysis of the Partici- } \\
\text { 'Learning Styles" }\end{array}$} \\
\hline & $\mathrm{N}$ & $\%$ \\
\hline (CS) & & 16,9 \\
\hline AS) & 73 & 15,2 \\
\hline R) & 149 & 31,0 \\
\hline R) & & 36,9 \\
\hline
\end{tabular}

The analysis has determined that, out of all the physical education and sports (PES) students which took part in the study, $36.9 \%(n=177)$ of the students have a concrete random (CR) learning style On the other hand, $31 \%(n=149)$ of the students have an abstract random (AR) learning style, $16.9 \%(\mathrm{n}=81)$ have a concrete sequential (CS) learning style and $15.2 \%(n=73)$ have an abstract sequential (AS) learning style.

Table 2. Frequency Analysis of the Participants' "Learning Styles" as per The "Department" Variable

\begin{tabular}{|c|c|c|c|c|c|c|c|c|c|}
\hline \multirow[t]{2}{*}{ Department type } & \multicolumn{2}{|c|}{$\mathrm{CS}$} & \multicolumn{2}{|c|}{ AS } & \multicolumn{2}{|c|}{ AR } & \multicolumn{2}{|c|}{$\mathrm{CR}$} & \multirow{2}{*}{$\frac{\text { Total }}{\mathrm{N}}$} \\
\hline & $\mathrm{N}$ & $\%$ & $\mathrm{~N}$ & $\%$ & $\mathrm{~N}$ & $\%$ & $\mathrm{~N}$ & $\%$ & \\
\hline PES & 29 & 23.0 & 18 & 14.3 & 32 & 2.4 & 47 & 37.3 & 126 \\
\hline $\mathrm{CE}$ & 35 & 18.0 & 29 & 14.9 & 65 & 33.5 & 65 & 33.5 & 194 \\
\hline SM & 17 & 10.6 & 26 & 16.2 & 52 & 32.5 & 65 & 40.6 & 160 \\
\hline
\end{tabular}

PES: Physical Education and Sports Teaching

\section{CE: Coaching Education}

\section{SM: Sports Management}

The result of the analyses shows that there is no meaningful difference in the learning styles of
When the learning styles of the students are evaluated according to the gender variable, it can be observed that $20.2 \%(n=52)$ of the female students have the CS learning style, $14.8 \%(n=38)$ have the AS, $28.0 \%(n=72)$ have the AR and $37.0 \%(n=95)$ have the CR learning style. On the other hand, out of all the male participants of the research $13.0 \%(n=29)$ have the $\mathrm{CS}, 15.7 \%$ $(n=35)$ have the AS, $34.5 \%(n=77)$ have the AR and $36.8 \%(n=82)$ have the CR learning style. Accordingly, the result of the analyses of the PES students' learning styles in relation to the gender variable shows that there is no meaningful difference between the groups. $[\mathrm{x} 2(\mathrm{sd}=3, \mathrm{n}=480)=5.39$, $\mathrm{p}>0.05]$. the physical education and sports school students with relation to the variable of the department they are enrolled in. [ $\mathrm{x} 2(\mathrm{sd}=6, \mathrm{n}=480)=9.86$, $\mathrm{p}>0.05]$. 


\begin{tabular}{|c|c|c|c|c|c|c|c|c|}
\hline \multicolumn{9}{|c|}{$\begin{array}{l}\text { April / May / June Spring Summer Issue: } 19 \text { Year: } 2016 \\
\text { GEL CODE: I0-I10-I11-I12-I21-M12-Z1 ID:287 K:203 } \\
\text { ISSN Print: 2146-8508 Online 2147-1711 } \\
\text { (ISO 9001-2008 Document No: 12879 ISO 14001-2004 Document No: 12880) } \\
\text { (TRADEMARK) } \\
\text { (2015/04315- 2015-GE-18972) }\end{array}$} \\
\hline \multicolumn{9}{|c|}{$\begin{array}{c}\text { dency Analysis of the Participants' Learning Styles as per the "Academ } \\
\text { Level" Variable }\end{array}$} \\
\hline $\mathrm{CS}$ & & AS & & $\mathrm{AR}$ & & CR & & Total \\
\hline $\mathrm{N}$ & $\%$ & $\mathrm{~N}$ & $\%$ & $\mathrm{~N}$ & $\%$ & $\mathrm{~N}$ & $\%$ & $\mathrm{~N}$ \\
\hline 20 & 12.5 & 26 & 16.2 & 46 & 28.8 & 68 & 42.5 & 160 \\
\hline 45 & 23.4 & 29 & 15.1 & 50 & 26.0 & 68 & 35.4 & 192 \\
\hline 13 & 13.5 & 12 & 12.5 & 40 & 41.7 & 31 & 32.3 & 96 \\
\hline 3 & 9.4 & 6 & 18.8 & 13 & 40.6 & 10 & 31.2 & 32 \\
\hline
\end{tabular}

The analysis made according to the variable of the academic level of the students shows meanand sports students' learning styles. $\left[\mathrm{x}^{2}\right.$ ingful difference between the physical education $(\mathrm{sd}=9, \mathrm{n}=480)=17.81, \mathrm{p}<0.05]$.

Table 4. Frequency Analysis of the Participants' Learning Styles as per the 'Perceived Academic Success" Variable

\begin{tabular}{llllllllll}
\hline \multirow{2}{*}{ Group } & CS & \multicolumn{3}{c}{ AS } & & AR & \multicolumn{2}{c}{ CR } & \multicolumn{3}{c}{ Total } \\
\cline { 2 - 10 } & $\mathrm{N}$ & $\%$ & $\mathrm{~N}$ & $\%$ & $\mathrm{~N}$ & $\%$ & $\mathrm{~N}$ & $\%$ & $\mathrm{~N}$ \\
\hline So Bad & 2 & 14.3 & 5 & 35.7 & 5 & 35.7 & 2 & 14.3 & 14 \\
\hline Bad & 14 & 13.1 & 9 & 8.4 & 38 & 35.5 & 46 & 43.0 & 107 \\
\hline Intermediate & 30 & 20.5 & 24 & 16.4 & 41 & 28.1 & 51 & 34.9 & 146 \\
\hline Good & 26 & 15.2 & 29 & 17.0 & 47 & 27.5 & 69 & 40.4 & 171 \\
\hline So Good & 9 & 21.4 & 6 & 14.3 & 18 & 42.9 & 9 & 21.4 & 42 \\
\hline
\end{tabular}

The analysis made according to the variable of the perceived academic success of the participants shows a meaningful difference between learning styles of physical education and sports students depending on their perceived academic success. $\left[\mathrm{X}^{2}(\mathrm{sd}=12, \mathrm{n}=480)=20.80, \mathrm{p}>0.05\right]$.

\section{DISCUSSION}

Many researches show that certain elements such as the individual's psychological characteristics, communication skills, training field and profession are effective in the shaping of an individual's learning styles (Gregorc \& Butler, 1984; Aşkar \& Akkoyunlu, 1993; Kolb \& Kolb, 2005). These elements are also effective in the division of the learning style into affective, physiological 


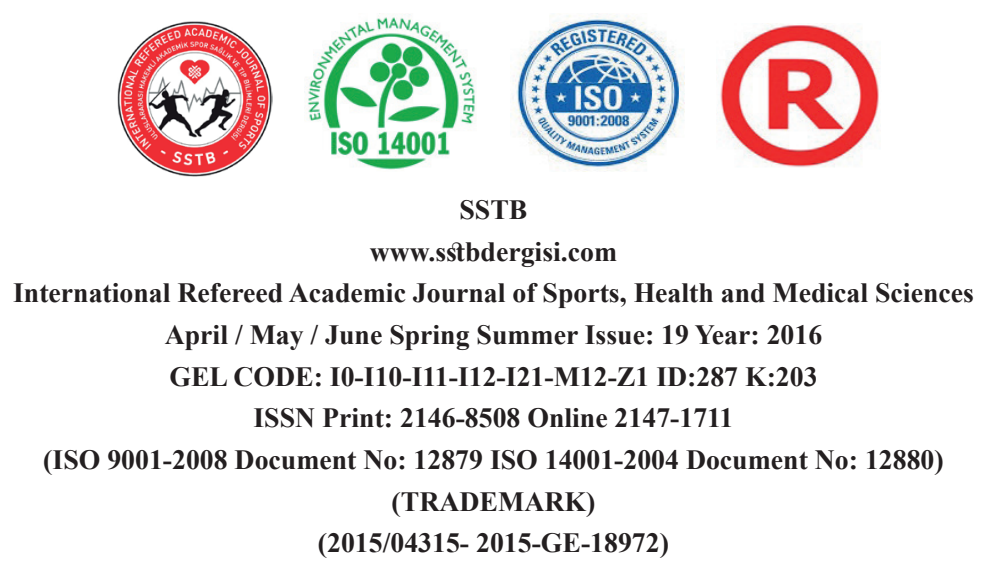

and cognitive dimensions (Cornet, 1983; Grasha, 1996; Ekici, 2013).

The following results have been reached in the study, which uses the Gregorc learning style model prepared on the cognitive dimension and aims to determine whether the learning styles of students enrolled in the Balıkesir University Physical Education and Sports School differ due to variables such as gender, the department they are enrolled in, academic level and their perceived academic success level:

The analysis has determined that, out of all the physical education and sports (PES) students which took part in the study, $36.9 \%(n=177)$ have a concrete random (CR) learning style. On the other hand, $31 \%(n=149)$ of the students have an abstract random (AR) learning style, 16.9\% $(n=81)$ have a concrete sequential (CS) learning style and $15.2 \%(n=73)$ have an abstract sequential (AS) learning style. (Table 1).

This result reveals that a majority of the Physical Education and Sports School students have a concrete random (CR) and abstract random (AR) learning style. Individuals with a concrete random (CR) learning style are better than the others about solving existing problems in comparison with others. While individuals have abstract random (AR) learning styles they don't need to certain order to perceive events and concepts (Ekici, 2013).
The findings of the research show that the difference observed between the learning styles of the physical education and sports school students is similar to the findings of various researches conducted in this field (Yalız \& Eriști, 2009; Küçük K1lıç \& Öncü, 2014; Alemdağ \& Öncü, 2015). The different teaching methods employed by the teachers in their educational background may be one of the key factors leading to the differentiation of the students' learning styles.

The difference between the learning styles of students within the same teaching environment puts a great responsibility upon teachers. Due to this reason, teachers have to include activities which take into account the learning styles and individual differences of their students while preparing their teaching plans (Karakış, 2006; Şimşek, 2007).

Gender is a variable that researches frequently focus on. The result of the analyses on whether the PES students' learning styles differ in relation to the gender variable shows no meaningful difference in this study either. This finding is parallel to most of the studies in this field (Hallock et al., 2003; Jones et al., 2003; Ames, 2003; Mutlu, 2008; Yalız \& Erişti, 2009). With this finding, it can be said that the gender factor does not affect the difference in the learning style of students.

The findings of the research also show that the learning styles of physical education and sports 


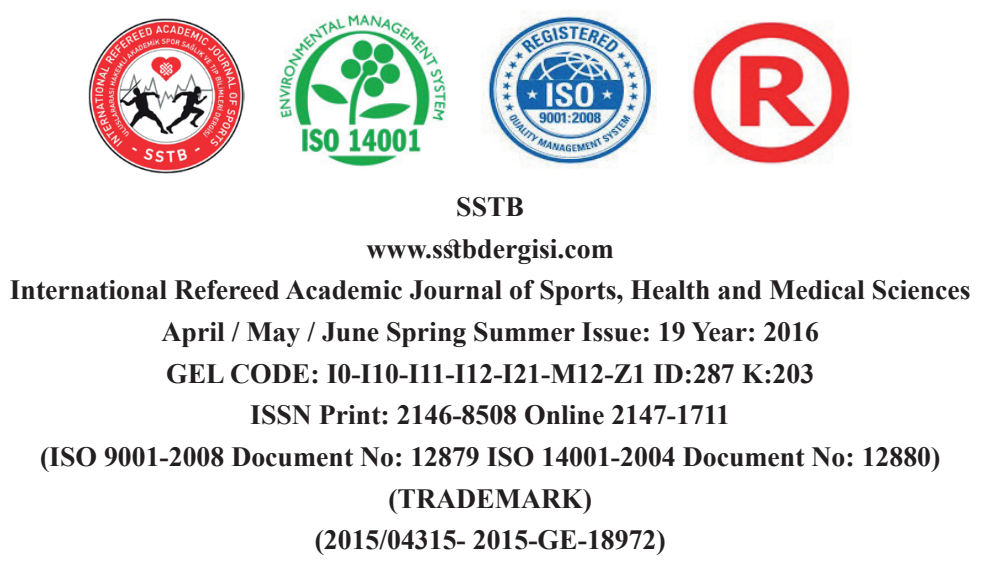

school students do not differ due to the variable of the department they are enrolled in. In other words, it has been observed that the difference between their departments do not affect their learning styles (Table 2).

The study has found a meaningful difference between the physical education and sports students' learning styles due to the variable of the academic level of the students (Table 3). This finding is parallel to the results of similar studies (Evin Gencel \& Köse, 2011; Özdemir \& Kesten, 2012; Katranc1 \&Bozkuş, 2014; Alemdağ \& Öncü, 2015). However, contrary to said findings, other studies in this field have found that the academic level of students do not affect their learning styles (Tuna, 2008; Yalız \& Erişti, 2009; Yenice, 2012). In the studies they conducted, researches have supported Kaplan and Kies' (1995) opinion that "the learning style is an inborn characteristic which does not easily change during the lifetime".

However, the reason why there is a difference in learning styles due to the academic level variable may be that the senior students are preparing for examinations necessary to enter their profession and thus are more focused on their cognitive dimensions during this period.

Similarly, previous studies in the field have pointed out that learning style preferences of students affect their academic success levels (Boatman et a.1. 2008; Chiou, 2008). The findings of this study have shown that the concrete random (CR) is the most preferred learning method of PES students with regards to academic success and that students who indicated their perceived academic success rate as very good prefer the abstract random (AR) learning method (Table 4). As Ekici (2013) stated, this result may be interpreted as a support of the opinion of students with a concrete dominant learning styles who claim that they do not find a satisfactory level of concrete learning opportunities during academic activities and perceive their success levels as low. This in turn supports the opinion that learning styles affect academic success (Clark \& Starr, 1996; Uzuntiryaki et al.,2003; Cengizhan, 2008; Ekici, 2013).

\section{CONCLUSION}

The analyses have determined that, out of all the PES students which took part in the study, 36.9 $\%$ of the students prefer the concrete random (CR) learning style. It has been observed that the learning styles of PES students do not have a meaningful correlation with variables such as gender, the enrolled program and perceived academic success $(p>0.05)$, however there is a meaningful difference with the variable of academic level $(\mathrm{p}<0.05)$.

This Literature survey on the topic shows that many theories and learning style models based on these theories have been developed. The results of this study show that similar findings are reached 


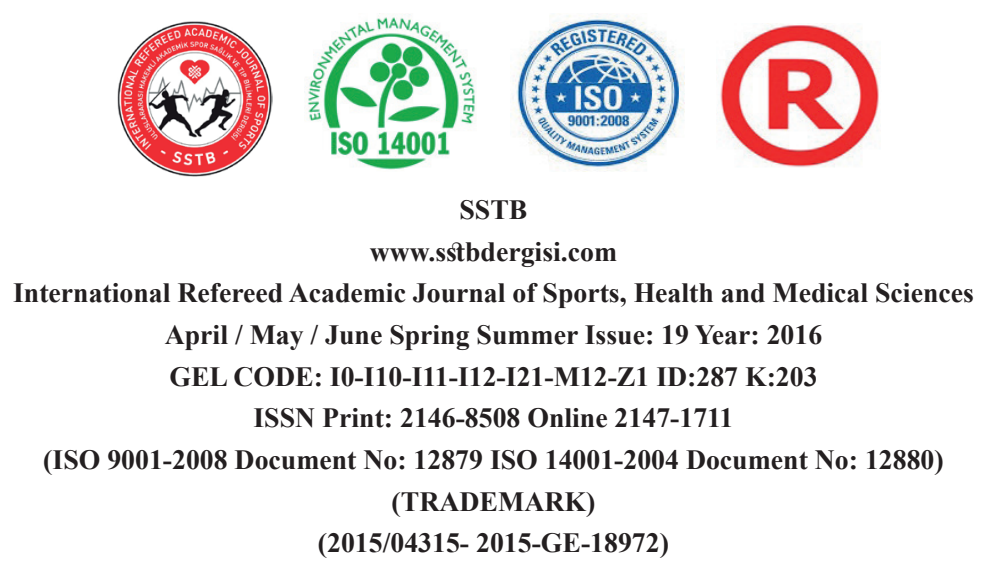

when the measuring tool of the same model is used on a similar sample group. The findings of this study is parallel to the findings of the study conducted by Yalnız and Erişti (2009) on the students enrolled in Anadolu University Physical Education and Sports School.

\section{RECOMMENDATIONS}

Below are some suggestions based on the findings of the research that we believe will contribute to the field. Accordingly;

The dominant learning styles of the students should be taken into account when planning the content of the curriculum at physical education and sports schools and the syllabus and teaching methods employed should include more stimulants and enable the students to use their creativity.

This study has been conducted with the Gregory learning style delineator prepared in the cognitive dimension. Studies can be conducted using other theories and models prepared in the cognitive, affective and physiological dimensions.

Future studies may employ different applications which support quantitative research techniques with qualitative research techniques.

\section{REFERENCES}

ALEMDA $\breve{G}, C$., \& $\ddot{O} N C \ddot{U}, E$., (2015). PreService Physical Education Teachers According to Kolb's Model of Learning Style.
Journal of Subject Teaching Research.1 (1).1-12

AMES, P.C., (2003). Gender and Learning Style Interactions in Students' Computer Attitudes. Journal of Educational Computing Research. 28 (3), 231-244. doi: 10.2190/M8CU-DE21BJF1-84MN

AŞKAR, P.,\& AKKOYUNLU, B., (1993). Kolb's Inventory of Learning Styles. Education and Science, No, 87, 37-47

BAHAR, H. H., ÖZEN, Y., \& GÜLAÇTI, F., (2009). An Investigation on Academic Achievement and Learnıng Styles as to Branches and Gender from Faculty of Education Students. Ankara University, Journal of Faculty of Educational Sciences, Vol: 42, No: 1, 69-86

BOATMAN K., COURTNEY, R., \& LEE, W., (2008). See How They Learn: The Impact of Faculty and Student Learning Styles On Student Performance In Introductory Economics. The American Economist, 52(1), 39-48

BURNS, D. E., JOHNSON, S.E., \& GABLE, R. K., (1998). Can We Generalize About the Learning Style Characteristics of High Academic Achievers? Roe per Review, 20 (4), 276-81 


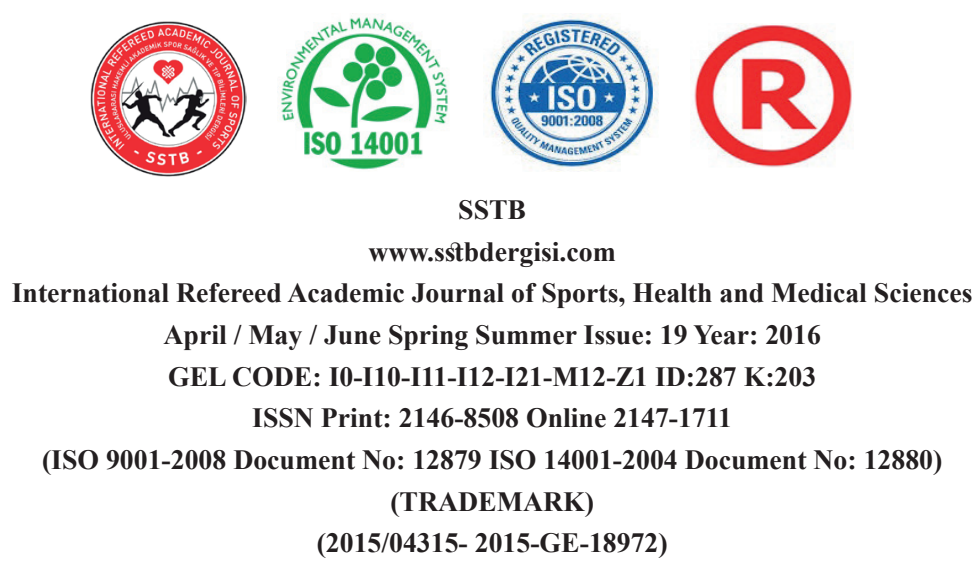

CLARK, L. H., \& STARR. I. S., (1996). Secondary and Middle School Teaching Methods. Englewood Cliffs, NJ: Prentice-Hall

CENGIZHAN, S., (2008). Determining The Effect Of Modular Instruction Design on The Academic Achievement And Long-Term Retention of Students With Different Learning Styles. Journal of Theory and Practice in Education. 4 (1): 98-116

CHIOU, W.B., (2008). College Students' Role Models, Learning Style Preferences and Academic Achievement In Collaborative Teaching: Absolute Versus Relativistic Thinking. Adolescence, 43(169), 129-142

CORNET, C. E., (1983). What You Should Know About Teaching And Learning Styles. Fastback 191, Bloomington Ind, 54p, Eric Document Ed 228235

DUNN, R., \& DUNN. K., (1993). Teaching Secondary Science Students Through Their Individual Learning Styles: Practical Approaches For Grades 7-12. New York. Allyn and Bacon

EKICI, G., (2002). Gregory Style Delineator. Education and Science, 27 (123), 42-48

EKICI, G., (2013). The Analysis of Teacher Candidates' Learning Styles In Terms Of Gender and Overall Academic Success According To Gregorc and Kolb Learning Style
Models. Education and Science. 38-167211-225

EVIN GENCEL, İ. \& KÖSE. A., (2011). Relationship between the Prospective Science Teachers' Learning Styles, Learning and Study Strategies, and Self-Efficacy Beliefs in Science Teaching. Journal of Theory and Practice In Education, 7(2), 311-333

GRASHA, A. F., (1996). Teaching with Style: A Practical Guide to Enhancing Learning by Understanding Teaching and Learning Styles. Pittsburgh: Alliance Publishers, Pp.154-158

GRENIER, M., (2006). A Social Constructionist Perspective of Teaching and Learning in Inclusive Physical Education. Adapted Physical Activity Quarterly, 23, 245-260

GOREVANOVA, A., (2000). The Relation Ship between Students'Perceptual Learning Style Preferences, Language Learning Strategies and English Language Vocabulary Size. Bilkent University, Ankara

GREGORC, A. F., (1982a). Gregorc Style Delineator-A Self-Assessment Instrument for Adults. Columbia: Gregorc Associates Inc

GREGORC, A. F., (1982b.) Gregorc Style Delineator: Development, Technical, And Administration Manual. Maynard, Ma: Gabriel Systems, Inc 


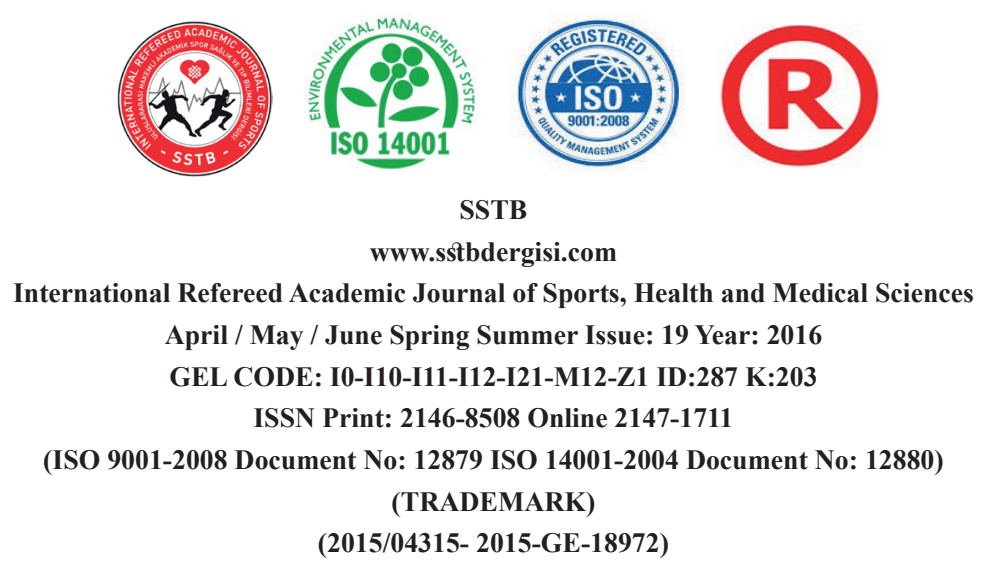

GREGORC, A. F., (1984). Style as a Symptom:

A Phenomenological Perspective. Theory Into Practice, 23(1)

GREGORC, A. F., \& BUTLER.K.A., (1984). Learning Is a Matter of Style". Vocational Education Journal, 59 (3):27-29

HALLOCK, D., SATAVA, D., \& LESAGE, T., (2003). An Exploratory Investigation of the Potential Relationship Between Student Learning Styles, Course Grade, Cumulative Grade Point Average and Selected Demographics in On-Line Undergraduate Business Courses, Management Research News, Vol:26, No 1, Pp.21-28

HUNT, D. E., (1979). Learning Style and Student Needs: An Introduction to Conceptual Level, Student Learning Styles: Diagnosing and Prescribing Programs. Reston, VA: National Association of Secondary School

JONES, C., REICHARD, C., \& MOKHTARI, K., (2003). Are Students' Learning Styles Discipline Specific? Community College Journal of Research and Practice, 27, 363375

KARAKIŞ, Ö., (2006). The Usage Level of General Learning Strategies of Students' Having Different Learning Styles at Some of the Higher Studies Institutions. Unpublished doctoral thesis, Curriculum Development and Instruction, Abant İzzet Baysal University. Bolu

KAPLAN, E. J., \& KIES, D. A., (1995). Teaching styles and learning styles. Journal of Instructional Psychology, 22 (1): 29-34

KATRANCI, Y., \& BOZKUŞ, F., (2014). Learning styles of prospective mathematics teachers: Kocaeli University Case. Procedia-Social and Behavioral Sciences, 116, 328-332

KILIÇ, E., (2002). The effect of the dominant learning style on learning activities preferences and academic achievement. Educational Sciences and Practice. 1 (1), 1-15

KOLB, A.Y., \& KOLB, D.A., (2005). The Kolb Learning Style Inventory-Version 3. Thecnical Specification. Boston, Ma: Hay Group Resources Direct

KOLB, A.Y., \& KOLB, D.A., (2005). Learning styles and learning spaces: enhancing experiential learning in higher education. Academy of Management Learning and Education, 4, 193-212

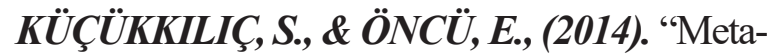
cognitive Learning Strategies and Academic Self-Efficacy of Physical Education and Sport School Students." Journal of Sports and Performance Researches.5. (2), P.13-22 


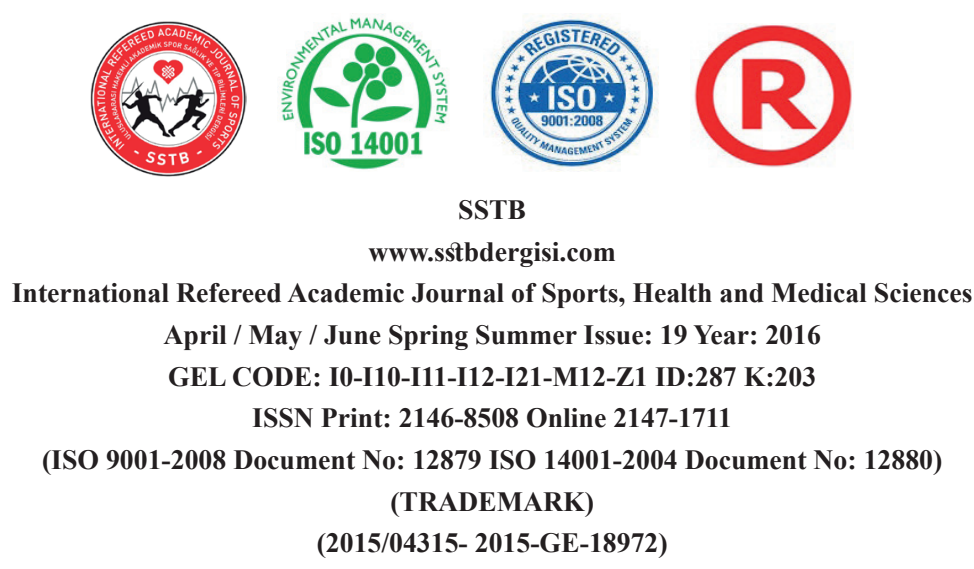

MUTLU, M., (2008). The Learning Styles of Education Faculty Students. Journal of Kazım Karabekir Education Faculty.17, 1-21

ÖZDEMIR, N., \& KESTEN, A., (2012). The Learning Styles of Prospective Social Studies Teachers' and The Relationship Between Demographic Characteristics. Atatürk University. Journal of Graduate School of Social Sclences.16 (1), 361-377

RISTORI, C. A., EBERMAN, L. E., TRIPP, B.L., \& KAMINSKI, T.W., (2011). Athletic Training Student Learning Style. International Journal of Athletic Therapy \& Training, 16(2), 33-37

SILVER, H., STRONG, R., \& PERINI, M., (1997). Integrating Learning Styles and Multiple Intelligences. Educational Leadership, 55(1), 22

ŞIMŞEK, Ö., (2007). The Development of Marmara Learning Style Inventory and Investigating 9-11 Age Students Learning Styles. Unpublished doctoral thesis, İstanbul: Marmara University
TUNA, S., (2008). The Learning Styles of Art Education Students. Electronic Journal of Social Sciences, 7(25), 252-261

UZUNTIRYAKI, E., BILGIN, İ., \& GEBAN, $\ddot{O}$., (2003). The Effect of Learning Styles on High School Students 'Achievement and Attitudes in Chemistry. Paper Presented at the annual meeting of The National Association for Research in Science Teaching. Philadelphia, Pa, (Eric Document Reproduction Service No: Ed 475 483)

YALIZ, D., \& ERIŞTI, B., (2009). Learning Styles of Students in The Department of Physical Education and Sports Teacher at Anadolu University". Celal Bayar University, Journal of Sport Science.4 (4)

YENICE, N., \& SARACALOĞLU, S., (2009). The Relationship between Learning Styles and Science Achievement of Preservice Elementary School Teachers. Yüzüncü Yll University, Journal of Faculty of Education.1 (1), 162-173 